\title{
Jurist-Diction
}

Volume 3 No. 6, November 2020

\section{Tanggung Gugat Badan Pengawas Obat dan Makanan Terhadap Peredaran Ranitidine}

\author{
Ani Rufaidah \\ Anirufaidah14@gmail.com \\ Universitas Airlangga
}

\begin{abstract}
How to cite:
Ani Rufaidah, 'Tanggung

Gugat Badan Pengawas

Obat dan Makanan Terhadap

Peredaran Ranitidine' (2020)

Vol. 3 No. 6 Jurist-Diction.

Histori artikel:

Submit 1 September 2020;

Diterima 22 September 2020;

Diterbitkan 1 November 2020 .

DOI:

10.20473/jd.v3i6.22956

\section{(c) (i) (2) (2)}

\begin{abstract}
Abstrak
Ranitidine pertama kali di legalkan di Indonesia pada tahun 1989, ranitidine merupakan suatu senyawa yang digunakan sebagai bahan paduan untuk menjadi obat. Fungsi ranitidine digunakan untuk menyembuhkan tukak lambung, gerd, dan maagh. Namun pada september 2019 FDA dan EMA menginformasikan bahwa didalam ranitidine terdapat kandungan cemaranNDMA(nitrosodymethylamine) yang justru dapat menimbulkan bahaya terbentuknya kanker sehingga beberapa izin edar ranitidine dicabut bahkan dimusnahkan karena kandungan NDMA (nitrosodymethylamine) melebihi ambang batas yang ditetapkan yakni $96 \mathrm{ng} /$ hari. Dari hasil peringatan tersebut, diketahui bahwa BPOM tidak menjalankan kewenangan dalam mengawasi peredaran obat setelah beredarnya suatu produk (postmarket) sebagaimana mestinya karena hal tersebut baru diketahui setelah 30 tahun ranitidine beredar dipasaran.

Kata Kunci: Tanggung Gugat; BPOM; Perlindungan Konsumen; Produk Obat.
\end{abstract}

\section{Pendahuluan}

Kesehatan merupakan keadaan sehat, baik kesehatan secara fisik maupun mental yang digunakan sebagai modal untuk melakukan seluruh aktifitas dan kegiatan kehidupan sehari-hari. Salah satu upaya yang dilakukan pemerintah yakni memberikan pelayanan yang terpadu dan terintegritas serta memperhatikan pencegahan, penyembuhan, pengurangan penderitaan agar kualitas penderita dapat terjaga seoptimal mungkin sesuai serta menyediakan dan menyalurkan obat-obatan Sesuai dengan Undang-Undang Nomor 36 Tahun 2009 Tentang Kesehatan. Obat terdiri dari berbagai macam obat-obatan dimulai dari golongan obat bebas, obat bebas terbatas, obat wajib apotek, obat keras, psikotropika, dan narkotika, hal ini dijelaskan oleh Peraturan Menteri Kesehatan Nomor 949/Menkes/Per/VI/2000 tentang Registrasi Obat Jadi. Masing-masing obat mempunyai kandungan tersendiri 
dengan dosis dan kegunaan yang berbeda. Dalam hal lain, obat dapat memberikan efek negatif bagi kesehatan bila tidak memenuhi persyaratan sesuai aturan yang berlaku. Maraknya peredaran dan penjualan obat yang mengandung zat berbahaya mengakibatkan banyak kasus bermunculan, salah satunya adalah studi kasus obat ranitidine. Ranitidine merupakan senyawa (kandungan) yang dijual dengan nama dagang cairan injeksi, Acran, Conranin, Radin, zantac. Ranitidine merupakan obat yang digunakan untuk mengurangi produksi asam lambung berlebih, obat ini sering digunakan sebagai obat sakit maag dan sering digunakan pula sebagai obat gejala penyakit tukak lambung dan tukak usus. ${ }^{1}$

Pada Tahun 1989 BPOM (Badan Pengawas Obat dan Makanan) memberikan persetujuan penjualan dan peredaran ranitidine melalui kajian evaluasi keamanan, khasiat, dan mutu. Seiringnya waktu berjalan selama 30 Tahun beredar pada tanggal 13 September 2019 pihak US Food and Drug Administration (FDA) dan European Medicine Agency (EMA) mengeluarkan peringatan melalui situs resmi FDA, bahwa didalam Ranitidine ditemukan cemaran yang diduga memicu timbulnya kanker. ${ }^{2}$ Diketahui bahwa cemaran tersebut ialah pengotor atau senyawa nitrosamine atau biasa disebut $N$-Nitrosodimethylamine (NDMA) yang termasuk dalam cemaran kimia yang berasal dari unsur atau senyawa kimia yang dapat membahayakan kesehatan manusia. NDMA yang ada pada ranitidine terbentuk karena faktor alami, dan bukan unsur kesengajaan yang dilakukan oleh manusia. NDMA merupakan cairan yang berwarna kuning dan tidak berbau. NDMA dapat terbentuk secara alami dengan berbagai proses pembuatan di industry, air, udara, dan tanah dari reaksi yang melibatkan bahan kimia lain yang disebut akilamin. ${ }^{3}$

${ }^{1}$ Pusat Informasi Obat Nasional Badan Pengawas Obat dan Makanan: Ranitidine, <http:// pionas.pom.go.id/monografi/ranitidin>, diakses pada tanggal 24 February 2020, pukul 19.16 WIB.

2 FDA.gov, FDA Updates and Press Announcements on ndma in zantac (ranitidine) $<\mathrm{https} / / /$ www.fda.gov/drugs/drug-safety-and-availability/fda-updates-and-press-announcements-ndma-zantac-ranitidine>, diakses pada tanggal 10 Februari 2020, pukul 10.00 WIB.

3 Dr.Fadhli Rizal Makarim "Ranitidine Tercemar NDMA, Benarkah Berisiko Kanker? (online), <https://www.halodoc.com/ranitidin-tercemar-ndma-benarkah-berisiko-kanker> diakses pada 24 February 2020, pukul 19.17 WIB. 
Senyawa nitrosamine sebenarnya di perbolehkan terlarut dalam obat, akan tetapi harus sesuai dengan batas maksimum yang diperbolehkan, namun pada kenyataannya senyawa yang ada pada beberapa obat ranitidine berada dalam kadar melebihi ambang batas maksimum yang diperbolehkan. Ambang batas yang diperbolehkan dalam kandungan obat ranitidine yakni 0,096 mikrogram (96 nanogram) acceptable daily intake yang artinya masyarakat boleh mengkonsumsi obat ranitidine tersebut dengan ambang batas tersebut atau setara dengan 0,32 ppm (part per million). Terhadap studi kasus di atas, konsumen harus mendapatkan perlindungan meskipun dalam kasus ranitidine tersebut, cemaran NDMA nya terbentuk secara alami. Dalam hal ini, tentunya bukan hanya membutuhkan tindakan dari pelaku usaha namun tindakan dari pemerintah sebagai bentuk upaya perlindungan bagi konsumen. Tentunya hal ini juga membutuhkan pengawasan, pembinaan dan tindakan dari Badan Pengawas Obat dan Makanan (BPOM) dimana BPOM mempunyai tugas dan kewenangan untuk mengawasi peredaran obat dan makanan yang sangat diperlukan sebagai bentuk perlindungan bagi konsumen masyarakat Indonesia dalam meningkatkan efektivitas pengawasan terhadap Obat dan Makanan yang beredar. Namun dalam realitanya BPOM dinilai terlambat dalam pengawasan obat serta menindaklanjuti ranitidine yang mengandung cemaran NDMA dengan kandungan melebihi batas ambang. ${ }^{4}$ BPOM dinilai terlambat karena negara-negara lain yang memproduksi obat dengan bahan baku ranitidine sudah melakukan penarikan dan pengujian jauh-jauh hari. Oleh karena itu, BPOM harus menerapkan dan menjunjung tinggi ketelitian dan sifat kehati-hatian dalam menjalankan tugasnya sebagai Badan Pengawas Obat dan Makanan. Hal tersebut bertujuan sebagai bentuk upaya penegakan hukum dan untuk melindungi konsumen dari hal-hal yang berbahaya.

\footnotetext{
4 Ai Rika Rachmawati, Ranitidin baru ditarik, BPOM dinilai lambat, <https://www.pikiranrakyat.com/nasional/pr-01320656/ranitidin-baru-ditarik-bpom-dinilai-lambat?page=2> diakses pada 20 april 2020, pukul 10.00 WIB.
} 


\section{Legalitas Obat Ranitidine sebagai produk obat di Indonesia}

Izin ialah suatu perbuatan hukum dalam administrasi negara yang dibuat untuk mengimplemntasikan peraturan berdasarkan prosedur dan persyaratan yang telah ditetapkan oleh peraturan perundang-undangan. perizinan mempunyai arti tersendiri yakni merupakan bentuk dari adanya pelaksanaan terkait fungsi pengaturan dan sifat pengendalian yang dimiliki oleh pemerintah.. ${ }^{5}$ Dalam peredaran obat tentunya pelaku usaha harus mempunyai izin edar. Obat merupakan bahan atau paduan, yang termasuk dalam produk biologi yang digunakan untuk mempengaruhi atau menyelediki sistem fisiologi atau keadaan patologi dalam rangka pentepan diagnosis, pencegahan, penyembuhan, peningkatan kesehatan, pemulihan, dan kontrasepsi untuk manusia. Obat yang diedarkan di wilayah Indonesia harus mempunyai izin edar yang diatur didalam Peraturan Menteri Kesehatan Republik Indonesia 1010/MENKES/PER/ XI/2008 Tentang Registrasi Obat. Pengaturan izin edar digunakan dengan tujuan untuk melindungi konsumen dari bahaya yang disebabkan oleh obat yang tidak memenuhi persyaratan mutu, tidak memenuhi standar, keamanan, manfaat/khasiat dalam kandungan yang ada pada obat tersebut. Dalam rangka melindungi konsumen dan beredarnya suatu obat pemerintah mempunyai beberapa pengawasan yang harus di perhatikan yakni pre-market dan post-market. Pre-market diberikan saat pemberian izin edar. Sedangkan post-market adalah salah satu upaya pengawasan dan pengujian yang harus dilakukan secara rutin pada produk yang telah di edarkan pada masyarakat. Setiap Obat yang akan diedarkan harus memilik izin edar yang telah disetujui oleh pihak BPOM. ${ }^{6}$ Oeh karena itu, dibuatlah Peraturan Kepala Badan Pengawas Obat dan Makanan Republik Indonesia Nomor 24 Tahun 2017 tentang Kriteria dan Tata Laksana Registrasi Obat. kriteria izin edar, yakni:

a. Khasiat yang meyakinkan dan keamanan yang memadai harus dibuktikan melalui uji nonklinik dan uji klinik atau bukti lain sesuai dengan status perkembangan ilmu pengetahuan;

5 Adrian Sutedi: Hukum Perizinan Dalam Sektor Pelayanan Publik (Sinar Grafika 2011) [168].

${ }^{6}$ Rahmi Yuningsih, 'Penguatan Kendali Pemerintah Terhadap Peredaran Obat dan Makanan' (2017) Vol.8 No.1 Jurnal Aspirasi.[14]. 
b. Mutu yang memenuhi syarat harus sesuai dengan standart yang telah ditetapkan, termasuk proses produksi sesuai dengan CPOB dan dilengkapi dengan bukti yang sahih;

c. Informasi produk dan label berisikan informasi yang lengkap, objektif dan tidak menyesatkan yang dapat menjamin penggunaan obat secara tepat, aman dan rasional.

Pemberian izin edar dari BPOM terhadap ranitidine tidak diberikan secara cumacuma, pemberian izin edar pada ranitidine diberikan melalui pengawasan pre-market (sebelum beredarnya suatu produk) yakni pengujian evaluasi, kemanan, kajian, dan mutu dari suatu obat. Hal itu digunakan sebagai jaminan bahwa produk obat tersebut terjamin kelayakan mutu, khasiat dan keamananya untuk diedarkan dan dipasarkan menurut ketentuan CPOB. Diketahui selama 30 tahun beredar ranitidine September 2019 ranitidine mengandung cemaran senyawa nitrosamine yang mengakibatkan terbentuknya kanker. Beberapa ranitidine setelah dikaji ulang oleh BPOM diketahui terdapat cemaran NDMA dengan kadar ambang melebihi batas yang telah ditentukan. Dari adanya temuan cemaran tesebut, ada beberapa produk ranitidine dari produksi Perusahaan yang berbeda-beda dicabut izin edarnya karena dirasa membahayakan kesehatan konsumen serta tidak sesuai dengan kriteria izin edar dari suatu produk obat menurut peraturan yang telah ditetapkan berdasarkan Undang-Undang Nomor 30 Tahun 2014 tentang Administrasi Pemerintahan diatur tentang pencabutan keputusan administrasi pemerintahan atau keputusan TUN didalam Pasal 64 Undang-Undang Nomor 30 Tahun 2014 tentang Administrasi selain itu pula diatur mengenai pembatalan keputusan administrasi pemerintahan pada pasal 66 Undang-Undang Nomor 30 Tahun 2014. Dalam hukum administrasi negara terdapat sebuah asas yang harus dipahami terlebih dahulu yakni contrarius actu. Asas contrarius actus dalam hukum administrasi negara adalah asas yang menyatakan badan atau pejabat negara (TUN) yang menerbitkan kTUN dengan sendirinya juga berwenang untuk membatalkannya. Asas contrarius actus berlaku meskipun dalam KTUN tidak adanya klausula pengaman yang lazim. Apabila dikemudian hari ternyata terdapat kekeliruan atau kekhilafan, maka keputusan 
yang dibuat akan ditinjau kembali. ${ }^{7}$ Adapun kriteria-kriteria KTUN dapat dicabut apabila terdapat cacat wewenang, prosedur, dan/atau substansi. Cacat substansi menurut Pasal 64 ayat (1) huruf C Undang-Undang Nomor 30 Tahun 2014, yakni: Keputusan tidak dilaksanakan oleh penerima keputusan sampai batas waktu yang telah ditentukan;

a. Fakta dan syarat-syarat hukum yang menjadi dasar keputusan telah berubah;

b. Keputusan yang dapat membahayakan dan merugikan kepentingan umum; atau

c. Keputusan yang tidak digunakan sesuai dengan tujuan yang tercantum didalam isi keputusan.

Pemberian izin edar obat harus memenuhi standarisasi suatu produk obat yang disosialisasikan sebagai bentuk perlindungan bagi konsumen, pelaku usaha, dan digunakan untuk meningkatkan produktivitas daya saing dalam menghasilkan barang yang layak diperdagangkan. Standarisasi Nasional diatur didalam Peraturan Pemerintah Nomor 102 Tahun 2000. Pemberian izin edar selain harus memenuhi standarisasi nasional, pembuatan obat harus di dilakukan menurut ketentuan CPOB (Cara Pembuatan Obat yang Baik). Pemberian izin edar dari BPOM terhadap ranitidine tidak diberikan secara cuma-cuma, pemberian izin edar pada ranitidine diberikan melalui pengawasan pre-market (sebelum beredarnya suatu produk) yakni pengujian evaluasi, kemanan, kajian, dan mutu dari suatu obat. Akhir Tahun 2019 dalam ranitidine ditemukan adanya cemaran NDMA, beberapa batch produk ranitidine di Indonesia mengandung cemaran dengan kadar yang melebihi batas ambang sehinga hal tersebut dapat menimbulkan terbentuknya kanker apabila produk ranitidine di konsumsi secara terus menerus. Kandungan NDMA yang ada didalam ranitidine terbentuk karena faktor alami dan bukan unsur kesengajaan yang dilakukan oleh manusia. karena dalam hal ini, diluar kendali produsen. NDMA yang terdapat pada ranitidine sebelumnya di uji menggunakan metode yang lama, namun hal tersebut tidak terdeteksi. Seiring berjalannya waktu, Press 2009).

Philipus Hadjon dan Tatiek Sri Djatmiati, Argumentasi Hukum (Gadjah Mada University 
Perkembangan kemajuan teknologi yang terus meningkat, dilakukan pengujian dan penelitian yang oleh farmakope menggunakan alat- alat pendeteksi dan alat ukur seperti LC-HRMS (Liquid Chromatography- HIGH RESOLUTION Mass Spectrometry) sehingga impurities NDMA dengan jumlah yang sangat kecil pun bisa terdeteksi. hasil pengujian tersebut ditemukan bahwa NDMA yang ada pada ranitidine merupakan hasil dekomposisi atau uraian (degradasi) yakni, adanya reaksi antara monochloramine dengan ranitidine yang menghasilkan zat yang disebut nitrosodimethylamine (NDMA). Reaksi degradasi inilah penyebab dari keberadaan NDMA dalam obat ranitidine. ${ }^{8}$ Sehingga dari penjelasan di atas, ada beberapa produk ranitidine ditarik dan dimusnahkan karena kandungan NDMA melebihi ambang batas dan dirasa membahayakan konsumen, namun ada juga kandungan NDMA yang ada dibawah ambang batas sehingga tetap boleh beredar dipasaran.

\section{Tanggung Gugat Badan Pengawas Obat dan Makanan terhadap Peredaran Ranitidine}

Sistem pengawasan obat dan makanan yang dibentuk di Indonesia bernama BPOM (Badan Pengawas Obat dan Makanan). ${ }^{9}$ Dengan adanya BPOM pengawasan pada produk obat dan makanan dapat dijangkau dengan mudah karena BPOM mempunyai jaringan nasional dan internasional serta memiliki kredibilitas professional yang bagus. Peraturan Badan Pengawas Obat dan Makanan yang selanjutnya disingkat BPOM diatur didalam Peraturan Presiden Nomor 80 Tahun 2017. Menurut Pasal 1 PP Nomor 80 Tahun 2017 Badan Pengawas Obat dan Makanan adalah: Lembaga Pemerintah non kementrian yang menyelenggarakan urusan pemerintah dalam bidang pengawasan obat dan makanan.

BPOM merupakan suatu Lembaga pemerintahan non kementrian yang dibuat untuk melaksanakan urusan pemerintah dalam mengawasi produk obat

\footnotetext{
8 Farmasetika; NDMA muncu dari reaksi degradasi produk ranitidine, $<$ https://farmasetika. com/2019/10/05/ndma-muncul-dari-reaksi-degradasi-produk-ranitidin/> diakses pada hari selasa, tanggal 19 Mei 2020, pukul 17.15 WIB.

9 Badan POM RI, Latar Belakang < https://www.pom.go.id/new/view/direct/background> diakses pada tanggal 17 Desember 2019, pukul 13.20 WIB.
} 
dan makanan. BPOM mempunyai hubungan yang erat dengan Dinas Kesehatan karena BPOM mempunyai kewenangan dalam peredaran, pengawasan produk obat dan makanan. ${ }^{10}$ Kedudukan BPOM ada dibawah dan bertanggung jawab kepada Presiden melalui Menteri yang juga ikut serta menyelenggarakan urusan pemerintah di bidang kesehatan. Dalam pasal 2 PP Nomor 80 Tahun 2017 tentang Badan Pengawas Obat dan Makanan diatur mengenai tugas-tugas yang harus dilakukan, yakni:

1. Dalammenjalankan tugas pemerintah,BPOMmemiliki tugas menyelenggarakan urusan pemerintah dalam bidang Pengawasan Obat dan Makanan sesuai dengan ketentuan yang ada didalam Peraturan Perundang-undangan.

2. Obat dan Makanan yang dimaksud pada ayat (1) terdiri dari obat, bahan obat, narkotika, psikotropika, precursor, zat adiktif, obat tradisional, suplemen kesehatan, kosmetik, dan pangan olahan.

Ditinjau dalam Pasal 3 pada PP Nomor 80 Tahun 2017 tentang Badan Pengawas Obat dan Makanan mempunyai fungsi utama yang harus diperhatikan, yakni:

a. Penyusunan kebijakan nasional dalam bidang pengawasan obat dan makanan;

b. Pelaksanaan kebijakan nasional dibidang pengawasan obat dan makanan;

c. Penyusunan dan penetapan norma, standar, prosedur, dan kriteria dibidang pengawasan sebelum beredar dan pengawasan selama beredar;

d. Pelaksanaan pengawasan sebelum beredar dan pengawan selama beredar;

e. Koordinasi pelaksanaan pengawasan Obat dan Makanan dengan instansi pemerintah pusat dan daerah;

f. Pemberian bimbingan teknis dan supervise dalam bidang pengawasan obat dan makanan;

g. Pelaksanaan penindakan terhadap pelanggaran ketentuan peraturan perundangundangan dibidang pengawasan obat dan makanan;

h. Koordinasi pelaksanaan tugas, pembinaan, dan pemberian dukungan administrasi kepada seluruh organisasi didalam lingkungan BPOM;

i. Pengelolaan barang milik/kekayaan negara yang menjadi tanggung jawab BPOM;

j. Pengawasan atas pelaksanaan tugas dilingkungan BPOM;

k. Pelaksanaan dukungan yang bersifat substantive kepada seluruh organisasi di lingkungan BPOM.

10 Henny G. Rahayu, Peranan BPOM dan Tanggung Gugat Terhadap Obat-Obatan yang Melanggar Undang-Undang Perlindungan Konsumen (Skripsi Fakultas Hukum Universitas Airlangga 2006).[21]. 
Dari uraian diatas dapat dijelaskan secara detail yang dimaksud dengan pengawasan sebelum beredar (pre-market) dan pengawasan selama beredar (postmarket. Pengawasan sebelum beredar merupakan pengawasan obat dan makanan sebagai tindakan pencegahan untuk menjamin obat dan makanan yang beredar memenuhi standar dan persyaratan keamanan, khasiat/manfaat. Dan mutu produk yang ditetapkan. Sedangkan pengawasan selama beredar adalah pengawasan obat dan makanan selama beredar dipasaran untuk memastikan bahwa obat dan makan yang beredar dimasyarakat telah memenuhi segala persyaratan terkait keamanan, manfaat, mutu produk yang telah ditetapkan oleh penegakan hukum. ${ }^{11}$

Didalam Peraturan Presiden Nomor 80 tahun 2017 juga diatur mengenai kewenangan BPOM dalam Pasal 4 yakni:

a. Dalam menerbitkan izin edar produk serta sertifikasi sesuai standar dan persyaratan keamanan, khasiat/manfaat dan mutu, serta pengujian obat dan makanan sesuai dengan ketentuan peraturan perundang-undangan di Indonesia;

b. Melakukan penyelidikan dan intelijen pada bidang pengawasan obat dan makanan sesuai dengan ketentuan peraturan peundang-undangan;

c. Pemberian sanksi berupa sansksi adminstrasi sesuai dengan ketentuan dan peraturan perundang-undangan yang berlaku.

Pihak Badan POM mempunyai tahapan registrasi obat untuk bisa memperoleh izin edar. Hal ini sesuai dengan pasal 2 peraturan Badan Pengawas Obat dan Makanan Nomor 24 Tahun 2017 Tentang Kriteria dan Tata Laksana registrasi Obat, menyebutkan:

1. Obat yang akan diedarkan dalam wilayah Indonesia wajib memiliki Izin Edar;

2. Untuk memperoleh Izin Edar harus melakukan registrasi terlebih dahulu;

3. Registrasi yang dilakukan harus ditujukan oleh pendaftar kepada Kepala Badan. Untuk memperoleh izin edar, suatu produk obat harus memenuhi syarat dan kriteria yang telah ditetapkan pada pasal 4 Peraturan Badan Pengawas Obat dan Makanan Nomor 24 Tahun 2017 tentang Kriteria dan tata laksana Didalam peraturan tersebut dijelaskan beberapa kriteria izin edar, yakni:

${ }_{11}$ Badan POM RI, Latar Belakang < https://www.pom.go.id/new/view/direct/background> diakses pada tanggal 17 Desember 2019, pukul 13.20 WIB. 
a. Khasiat yang meyakinkan dan keamanan yang memadai harus dibuktikan melalui uji nonklinik dan uji klinik atau bukti lain sesuai dengan status perkembangan ilmu pengetahuan;

b. Mutu yang memenuhi syarat harus sesuai dengan standart yang telah ditetapkan, termasuk proses produksi sesuai dengan CPOB dan dilengkapi dengan bukti yang sahih;

c. Informasi produk dan label berisikan informasi yang lengkap, objektif dan tidak menyesatkan yang dapat menjamin penggunaan obat secara tepat, aman dan rasional.

Pengawasan Obat dan Makanan yang dilakukan oleh BPOM merupakan proses yang bersifat komprehensif. Pengawasan yang dilakukan secara komprehensif mencakup 2 jenis pengawasan pre-market dan post market. System pengawasan yang dibuat oleh BPOM berdasarkan Peraturan Presiden Nomor 80 Tahun 2017, yakni yang mencakup: ${ }^{12}$

a. Standarisasi, standarisasi merupakan suatu fungsi penyusunan regulasi, standar dan kebijakan yang terkait dengan pengawasan obat dan makanan. Dengan dibentuknya standarisasi ditujukan sebagai alat untuk menghindari adanya perbedaan standar yang mungkin terjadi karena setiap provinsi memiliki dan membuat standar tersendiri;

b. Penilaian (pre-market evaluation) pengawasan pre-market evaluation merupakan pengawasan produk sebelum memperoleh nomor izin edar dan dapat diproduksi dan diedarkan kepada konsumen. Penilaian ini dimaksudkan agar produk yang memiliki izin edar berlaku secara nasional dan tidak menimbulkan bahaya bagi konsumen;

c. Pengawasan selama beredar (pre-market evaluation) pengawasan ini dilakukan untuk mengecek konsistensi mutu produk, keamanan dan informasi produk yang dilakukan dengan melakukan sampling produk baik obat ataupun makanan yang beredar dikalangan masyarakat. Pengawasan ini dilakukan secara terpadu, konsisten, dan terstandar. Dalam menjalankan kegiatan pengawasan pre-market evaluation melibatkan Balai Besar/Balai POM di 33 Provinsi dan wilayah yang sulit dijangkau oleh Pengawasan Obat dan Makanan (Pos POM);

d. Pengujian laboratorium. Produk yang diuji melalui laboraturium digunakan untuk mengetahui apakah obat tersebut telah memenuhi persyaratan atas keamanan, khasiat/manfaat dan mutu. Hasil uji laboratorium ini merupakan

12 Badan POM RI, "Sasaran Strategis" https://www.pom.go.id/new/view/direct/strategic, diakses pada tanggal 17 Desember 2019, Pukul 14.15 WIB. 
dasar ilmiah yang digunakan untuk menetapkan suatu produk yang tidak berstandar dan tidak memenuhi persyaratan dan ditarik dari peredaran;

e. Penegakan hukum dibidang pengawasan obat dan makanan didasarkan pada bukti hasil pengujian, pemeriksaan dan ivestigasi awal. Penegakan hukum berakhir dengan pemberian sanksi administrasi seperti ditarik dari peredaran, disita untuk dimusnahkan. Namun, jika pelanggaran masuk kedalam ranah pidana, maka proses penegakan hukumnya dapat diproses secara hukum pidana.

Sesuai penjelasan keterangan diatas, Pengawasan Post-Market dibuat dengan tujuan sebagai jaminan untuk memastikan bahwa produk obat dan makanan telah tetap memenuhi persyaratan kemanfaatan, keamanan, dan mutu yang sebelumnya telah di setujui oleh BPOM sebelum beredar di pasaran. Pengawasan yang dilakukan oleh BPOM dilakukan setiap waktu. Pengawasan Post-Market dibagi menjadi 2 (dua) kategori yakni pengawasan rutin dan pengawasan khusus. Berikut system pengawasan rutin yang dilakukan BPOM dalam pengawasan Post-Market: ${ }^{13}$

a. Pemeriksaan dalam sarana produksi dimaksudkan untuk mengetahui apakah proses produksi obat dan makanan telah menerapkan cara produksi dengan baik;

b. Memonitoring produk yang beredar dipasaran. Yang dimaksud memonitoring yaitu melakukan pengawasan selama beredar untuk memastikan obat dan makanan tetap memenuhi standar dan persyaratan keamanan, khasiat/manfaat, dan mutu dalam hal kadaluwarsa, rusaknya suatu produk, dan mengandung bahan berbahaya;

c. Pengawasan label dan iklan;

d. Pengawasan sarana pelayanan terhadap kefarmasian;

e. Pemeriksaan sarana sitribusi obat dan makanan;

f. Sampling dan pengujian;

g. Monitoring efek samping dari suatu produk baik makanan maupun obat.

Selain melakukan pengawasan rutin secara berkala, BPOM juga melakukan pengawasan secara khusus yang meliputi beberapa hal, yakni:

a. Intensifikasi pemberantasan produk illegal atau tanpa izin edar. Memberantas produk-produk yang illegal dan berbahaya dan merugikan bagi konsumen

b. Pengawasan penjualan melalui media online

c. Pengawasan dengan target khusus berbagai operasi skala nasional maupun operasi internasional

d. Intensifikasi pengawasan obat dan makanan menjelang hari besar keagamaan atau menjelang tahun baru. 
Kasus Ranitidine yang mengandung cemaran NDMA di uji Kembali oleh BPOM pada tanggal 17 September 2019. Pengujian yang dilakukan oleh BPOM selama 30 Tahun beredar, tidak ditemukannya cemaran NDMA hal tersebut dikarenakan pada pengujian mutu dalam impurieties mempunyai beberapa metode analisis yang ditemukan, maka dalam pengujian tersebut harus ditambahkan $2 \mathrm{x}$. Dalam hal ini, BPOM mempunyai keterbatasan dalam pengawasan, disertai dengan tidak update terkait metode-metode terbaru untuk pengujian ulang serta ranitidine kurang mendapat perhatian dari pihak farmakope luar. Farmakope merupakan suatu buku resmi suatu negara yang ditetapkan secara hukum dan didalamnya memuat standarisasi obat-obatan, persyaratan identitas, sifat-sifat kimia maupun fisika, kadar dari suatu obat, kemurnian, sediaan farmasi, cara pemeriksaan dan/atau analisis. ${ }^{14}$ Maka dalam hal ini, BPOM dianggap tidak menjalankan kewenangannya sebagaimana mestinya karena BPOM seharusnya mengetahui akan tugasnya tapi tidak dilakukan dengan baik, oleh karena itu pihak yang merasa dirugikan oleh pengawasan BPOM dapat menggugat BPOM dengan dasar Pasal 1365 Kitab Undang-Undang Hukum Perdata yang dikatakan sebagai perbuatan melanggar hukum. Pasal 1365 KUH Perdata berbunyi: "Setiap Perbuatan melanggar hukum, yang membawa kerugian kepada orang lain, mewajibkan orang yang karena salahnya menerbitkan kerugian itu, mengganti kerugian tersebut".

Tanggung gugat oleh BPOM dalam Perbuatan Melawan Hukum, didasari pada Perbuatan Melawan Hukum Onrechtmatige Overheidsdaad karena BPOM berkedudukan dalam badan/pejabat yang melaksanakan urusan pemerintahan, sehingga dalam hal ini BPOM termasuk dalam lingkup Penguasa menurut Pasal 1 angka 6 Jo Pasal 1 angka 2 UU No.5 Tahun 1986 yang sudah diubah dengan UU No. 9 Tahun 2004 tentang Peradilan Tata Usaha Negara. Perbuatan Melawan Hukum oleh penguasa Onrechtmatige Overheidsdaad dapat diselesaikan melalui Pengadilan Tata Usaha Negara yakni yang mempunyai kewenangan dalam

${ }^{14}$ Farmakope, 'SejarahFarmasi', <https://sejarahfarmasi.wordpress.com/2016/04/20/farmakope/> diakses pada tanggal 14 Juni 2020, Pukul 13.15 WIB. 
memeriksa dan menyelesaikan sengketa PMH oleh penguasa. ${ }^{15}$ Suatu perbuatan yang dikategorikan sebagai pebuatan melanggar hukum apabila telah memenuhi unsur-unsur berikut:

1. Adanya perbuatan melanggar hukum

2. Adanya unsur kesalahan dari perbuatan tersebut

3. Adanya kerugian pada korban akibat dari perbuatan tersebut

4. Adanya hubungan kausal antara perbuatan yang dilakukan dengan kerugian yang timbul ${ }^{16}$

Perlindungan bagi masyarakat terhadap Perbuatan Melawan Hukum yang dilakukan oleh penguasa atau disebut Onrechtmatige Overheidsdaad juga diatur didalam PERMA Nomor 2 Tahun 2019. Perma Nomor 2 Tahun 2019 menjelaskan bahwa dalam rangka untuk memberikan jaminan perlindungan kepada masyarakat, undang-undang tersebut akan memungkinkan warga atau masyarakat dalam mengajukan gugatan terhadap keputusan dan/atau tindakan badan da/atau pejabat pemerintahan kepada Peradilan Tata Usaha Negara. Perma Nomor 2 Tahun 20109 tidak mengatur mengenai ukuran atau parameter ganti rugi. Namun, dalam realitanya inti dari PMH adalah penggantian rugi dari penguasa karena adanya kerugian yang disebabkan dilanggarnya suatu hukum. Sedangkan Perbuatan Melawan Hukum dengan arti luas menurut Putusan HR. 31 Januari 1919- Drukker Arrest dalam kasus Lindenbaum-Cohen yakni: ${ }^{17}$

"Berbuat atau tidak berbuat yang melanggar hak orang lain, atau bertentangan dengan kewajiban hukum pelaku, atau bertentangan dengan kesusilaan, atau bertentangan dengan kecermatan yang harus diperhatikan dalam lalu lintas masyarakat terhadap diri atau barang orang lain".

Didalam kasus Lindenbaum-Cohen disebutkan beberapa unsur Onrechtmatige Overheidsdaad yakni mengenai perbuatan melawan hukum berbuat atau tidak berbuat yang: ${ }^{18}$

1. Melanggar hak orang lain, atau;

2. Bertentangan dengan kewajiban hukum pelaku, atau;

\footnotetext{
15 ibid.[3].

${ }^{16}$ Munir Fuady, Perbuatan Melawan Hukum (pendekatan Kontemporer) (Citra Aditya Bakti 20020.[10].

${ }_{17}$ Yudha Hernoko, Slide Perkuliahan Hukum Perikatan (Airlangga University).[139].

18 ibid.[139].
} 
3. Bertentangan dengan kesusilaan, atau;

4. Bertentangan dengan kepatutan dan kecermatan yang terdapat didalam masyarakat terhadap diri atau barang orang lain.

Berbeda dengan citizen lawsuit. Citizien Lawsuit merupakan suatu gugatan yang dapat diajukan oleh setiap orang terhadap suatu perbuatan melawan hukum, dengan mengatas namakan kepentingan umum, berdasarkan peraturan perundangundangan yang telah mengatur adanya prosedur tersebut. Selain itu gugatan Citizen Lawsuit yang diajukan dengan harapan dipenuhinya hak-hak asasi manusia (karena sudah masuk di UUD 1945, yang disebut sebagai pengawal konstitusi (UUD 1945), maka dari situlah Mahkamah Konstitusi dituntut untuk menjamin bahwa UUD 1945 benar-benar ditaati dalam praktiknya, termasuk dalam menjamin hak-hak konstitusional warga negara dengan benar-benar dihormati, dilindungi, dan dipenuhi dalam praktiknya. Gugatan dalam Citizien Lawsuit diajukan pada lingkup Peradilan Umum yang dalam hal ini termasuk perkara perdata. Ada dua alasan mengapa citizien lawsuit di ajukan di peradilan umum yakni pertama karena kekuasaan kehakiman pertama kali citizen lawsuit muncul di Indonesia, hanya ada Mahkamah Agung. Yang kedua, belum adanya regulasi yang mengatur citizen lawsuit di Indonesia, sehingga dengan berpatokan pada asas "hakim tidak boleh menolak suatu perkara dengan dalil tidak ada dasar hukumnya”, maka istilah itu yang kemudian digunakan sebagai latarbelakang Citizen Lawsuit di Indonesia diajukan di Peradilan Umum.

Karakteristik dalam citizen law suit, yakni:

a. Tergugat dalam citizen lawsuit adalah penyelenggara negara, dimana dimulai dari presiden, wakil presiden sebagai pimpinan teratas, Menteri dan sampai kepada pejabat negara dibidang yang dianggap telah melakukan kelalaian dalam memenuhi hak warga negaranya;

b. Perbuatan melawan hukum yang dalam gugatan adalah karena kelalaian penyelenggara negara dalam pemenuhan hak warga negara;

c. Penggunggat adalah warga negara yang merasa dirugikan dan yang bertindak mengatasnamakan warga negara;

d. Citizien law suit tidak memerlukan adanya suatu notifikasi Option Out setelah gugatan didaftarkan sebagaimana diatur dalam PERMA tentang class action;

e. Petitum yang ada didalam gugatan tidak boleh meminta adanya ganti rugi materil dan memiliki kesamaan kerugian dan kesamaan fakta hukum sebagaimana gugatan pada class action; 
f. Petitum dalam citizien law suit harus berisikan permohonan agar negara mengeluarkan suatu kebijakan yang mengatur umum (Regeling) dengan tujuan perbuatan melawan hukum berupa kelalaian dalam pemenuhan hak warga negara tersebut dimasa yang akan mendatang tidak terjadi lagi.

Selain itu ada beberapa karakteristik yang lain dari gugatan citizen lawsuit, yakni: ${ }^{19}$

a. Citizen lawsuit merupakan akses orang per orang atau warga negara untuk mengajukan permohonan di pengadilan untuk dan atas nama kepentingan keseluruh warga negara atau pada kepentingan publik;

b. Citizen lawsuit bertujuan untuk melindungi warga negara dari kemungkinan terjadinya kerugian sebagai akibat dari Tindakan atau pembiaran negara;

c. Citizien lawsuit memberikan kekuatan kepada warga negara untuk menggugat negara dan institusi pemerintah yang melakukan pelanggaran undang-undang atau yang melakukan kegagalan dalam memenuhi kewajibannya dalam pelaksanaan (implementasi) undang-undang;

d. Orang perorangan atau warga negara yang menjadi pemohon dalam gugatan citizen lawsuit tidak perlu membuktikan adanya kerugian langsung yang bersifat riil atau tangible.

Oleh karena itu, dapat disimpulkan atas kelalaiannya dalam petitum gugatan, negara dihukum untuk mengeluarkan suatu kebijakan yang sifatnya mengatur umum dengan maksud agar hal tersebut tidak terjadi lagi di kemudian hari.

Dalam kasus ranitidine, para pihak yang merasa dirugikan oleh pengawasan BPOM terhadap obat ranitidine dimana BPOM lalai melakukan penyelenggaraan pengawasan post market yakni salah satunya dengan memonitoring produk yang beredar dipasaran sesuai PP Nomor 80 Tahun 2017 tentang Badan Pengawas Obat dan Makanan. Memonitoring yaitu melakukan pengawasan selama berdar dengan tujuan agar suatu produk khasiat, manfaat, dan mutunya terjamin seperti awal diberikannya pada saat izin edar, hal itu tidak diketahui oleh BPOM bahwa ranitidine mengandung cemaran NDMA dan diketahui beberapa produk ranitidine mengandung cemaran melebihi batas ambang yang telah ditetapkan, sehingga para pihak yang merasa dirugikan dapat mengajukan gugatan Citizien Lawsuit dengan dasar PMH karena dalam hal ini BPOM dapat dihukum untuk mengeluarkan suatu

${ }^{19}$ Abdul Fatah, 'Gugatan Warga Negara sebagai mekanisme pemenuhan hak asasi manusia dan hak konstitusional warga negara' (2013) Volume 28 Nomor 3 Jurnal Ilmu Hukum.[297]. 
kebijakan dengan maksud kelalaian tersebut tidak terjadi lagi dikemudian hari. ${ }^{20}$ Berbeda pula dengan Class Action, class action merupakan gugatan perwakilan kelompok yang diatur didalam Perma No. 1 Tahun 2002. Gugatan Perwakilan Kelompok atau disebut Class Action berdasarkan pasal 1 huruf a yakni: ${ }^{21}$

"Merupakan suatu tata cara pengajuan gugatan dalam mana satu orang atau lebih yang mewakili kelompok mengajukan gugatan untuk diri atau diri mereka sendiri dan sekaligus mewakili sekelompok orang yang jumlahnya banyak. Dan dengan memiliki kesamaan fakta atau dasar hukum antara wakil kelompok dengan anggota kelompok yang dimaksud".

Adapun unsur dari class action ialah:

1. Gugatan yang dilakukan secara perdata;

2. Wakil kelompok (Class Representative);

3. Anggota Kelompok (Class Members);

4. Adanya Kerugian;

5. Kesamaan Peristiwa atau fakta dan disertai dengan dasar hukum yang relevan.

\section{Kesimpulan}

Legalitas ranitidine sebagai produk obat di Indonesia, telah diberikan sejak tahun 1989, namun adanya temuan cemaran NDMA dalam ranitidine pada tahun 2019 mengakibatkan ada sejumlah ranitidine yang ditarik dan dicabut izin edarnya dari peredaran sehingga tidak diperdagangkan kembali dan dismunahkan. Namun ada beberapa juga yang dilegalkan kembali kemasyarakat karena dirasa aman untuk dikonsumsi. Badan Pengawas Obat dan Makanan bertanggung gugat dengan didasari pada pasal 1365 KUH Perdata karena BPOM tidak melaksanakan kewenangannya mengawasi peredaran obat-obatan yang sesuai dengan ketentuan peraturan perundang-undangan yang telah ditetapkan, selain itu pihak-pihak yang merasa dirugikan karena lemahnya pengawasan BPOM dalam melaksanakan kewenangannya mengawasi peredaran obat-obatan yang tdak sesuai dengan standar produksi yang telah ditetapkan dapat mengajukan gugatan dengan dasar PMH dan menggunakan gugatan Citizen Lawsuit.

${ }^{20}$ Annisa Gustin Ekaputri, Perbandingan Class Action, Citizien Law suit dan Legal Standing, $<$ https://www.academia.edu/35894703/Perbandingan_Class_Action_Legal_Standing_dan_Citizen_Lawsuit_dalam_Hukum_Acara_Perdata.docx, > diakses 13 Juni 2020,pukul 14.00 WIB.

21 ibid. 


\section{Daftar Bacaan}

\section{Buku}

Adrian Sutedi, Hukum Perizinan Dalam Sektor Pelayanan Publik (Sinar Grafika, 2011).

Philipus Hadjon dan Tatiek Sri Djatmiati, Argumentasi Hukum (Gadjah Mada University 2009).

Munir Fuady, Perbuatan Melawan Hukum (pendekatan Kontemporer) (Citra Aditya Bakti 2002).

Yudha Hernoko, Slide Perkuliahan Hukum Perikatan (Airlangga University 2017).

\section{Jurnal}

Rahmi Yuningsih, Penguatan Kendali Pemerintah Terhadap Peredaran Obat dan Makanan' (2017) Jurnal Aspirasi Ilmu Hukum.

\section{Laman}

Pusat Informasi Obat Nasional Badan Pengawas Obat dan Makanan, 'Ranitidine', $<$ http://pionas.pom.go.id/monografi/ranitidin>,Diakses pada Hari Senin Tanggal 24 February 2020, Pukul 19.16 WIB.

FDA.gov, 'FDA Updates and Press Announcements on ndma in zantac (ranitidine)', $<$ https://www.fda.gov/drugs/drug-safety-and-availability/fda-updates-andpress-announcements-ndma-zantac-ranitidine>, diakses pada tanggal 10 Februari 2020, Pukul 10.00 WIB.

Dr.Fadhli Rizal Makarim, 'Ranitidine Tercemar NDMA, Benarkah Berisiko Kanker?', <https://www.halodoc.com/ranitidin-tercemar-ndma-benarkahberisiko-kanker>, diakses pada 24 February 2020, Pukul 19.17 WIB.

Ai Rika Rachmawati, 'Ranitidin baru ditarik, BPOM dinilai lambat', <https:// www.pikiran-rakyat.com/nasional/pr-01320656/ranitidin-baru-ditarik-bpomdinilai-lambat?page $=2>$, diakses pada 20 april 2020, Pukul 10.00 WIB.

Farmasetika, 'NDMA muncul dari reaksi degradasi produk ranitidine', $<$ https:// farmasetika.com/2019/10/05/ndma-muncul-dari-reaksi-degradasi-produkranitidin/>, diakses pada hari selasa, tanggal 19 Mei 2020, Pukul 17.15 WIB.

Badan POM RI, 'Latar Belakang' <https://www.pom.go.id/new/view/direct/ background $>$, diakses pada tanggal 17 Desember 2019, Pukul 13.20 WIB. 
Badan POM RI, 'Sasaran Strategis'<https://www.pom.go.id/new/view/direct/ strategic $>$, diakses pada tanggal 17 Desember 2019, Pukul 14.15 WIB.

Farmakope, 'SejarahFarmasi' , < https://sejarahfarmasi.wordpress.com/2016/04/20/ farmakope/>, diakses pada tanggal 14 Juni 2020, Pukul 13.15 WIB.

\section{Perundang-undangan}

Undang-Undang Dasar Negara Republik Indonesia Tahun 1945.

Kitab Undang-undang Hukum Perdata Burgerlijk Wetboek, Staatsblad 1847 Nomor 23).

Undang-Undang Nomor 8 Tahun 1999 tentang Perlindungan Konsumen (Lembaran Negara Tahun 1999 Nomor 42, Tambahan Lembaran Negara Nomor 3821).

Undang-Undang Nomor 36 Tahun 2009 tentang Kesehatan (Lembaran Negara Tahun 2009 Nomor 144, Tambahan Lembaran Negara Nomor 5063).

Undang-Undang Nomor 30 Tahun 2014 tentang Administrasi Pemerintahan (Lembaran Negara Tahun 2014, Tambahan Lembaran Negara Nomor 292).

Peraturan Presiden Nomor 80 Tahun 2017 tentang Badan Pengawas Obat dan Makanan (Lembaran Negara Tahun 2017 Nomor 180).

Peraturan Badan Pengawas Obat dan Makanan Nomor 34 Tahun 2018 Tentang Pedoman Cara Pembuatan Obat yang Baik (Berita Negara Tahun 2018 Nomor 1600). 